\title{
$n$-Alkanes in surficial sediments of Visakhapatnam harbour, east coast of India
}

\author{
V R Punyu*, R R Harji, N B Bhosle, S S Sawant and K Venkat \\ Marine Corrosion and Material Research Division, National Institute of Oceanography, \\ Dona Paula, 403 004, Goa, India. \\ *Corresponding author.e-mail: rpunyu@gmail.com
}

Surface sediments collected from 19 stations along Visakhapatnam harbour were analysed for organic carbon (OC), $\delta^{13} \mathrm{C}_{\mathrm{oc}}$, total lipids (TL), total hydrocarbon (THC), $n$-alkane concentration and composition. OC, $\delta^{13} \mathrm{C}_{\mathrm{oc}}$, TL and THC ranged from $0.6 \%$ to $7.6 \%,-29.3$ to $-23.8 \%$, 300 to $14,948 \mu \mathrm{g} \mathrm{g}^{-1} \mathrm{dw}$, and 0.2 to $2,277 \mu \mathrm{g} \mathrm{g}^{-1} \mathrm{dw}$, respectively. Predominance of even carbon numbers $n$-alkanes $\mathrm{C}_{12}-\mathrm{C}_{21}$ with carbon preference index (CPI) of $<1$ suggests major microbial influence. Fair abundance of odd carbon number $n$-alkanes in the range of $\mathrm{C}_{15}-\mathrm{C}_{22}$ and $\mathrm{C}_{23}-\mathrm{C}_{33}$ indicates some input from phytoplankton and terrestrial sources, respectively. Petrogenic input was evident from the presence of hopanes and steranes. The data suggest that organic matter $(\mathrm{OM})$ sources varied spatially and were mostly derived from mixed source.

\section{Introduction}

In coastal sediments, organic matter (OM) is derived from various sources including autochthonous and allochthonous sources. Transport and storage of $\mathrm{OM}$ in coastal areas assume much significance as these areas play an important role in global carbon cycle, and also serve as a source of OM to the open ocean (Gogou et al. 2000; Bouloubassi et al. 2001). The role played by coastal areas in both natural and disturbed carbon cycle is yet to be fully understood in terms of global carbon change (Wu et al. 2001). In order to better understand the process of carbon cycling, it is essential to characterize the nature and sources of OM.

A number of compounds including carbohydrates, lignin phenols and lipids are often used to evaluate the nature and sources of OM. Lipids account for a small fraction of OM but when characterised at molecular level, they provide valuable information on the sources of OM (Meyers 2003; Volkman 2006). For example, lipid compounds such as $n$-alkanes, sterols, alcohols and fatty acids are used to assess sources of OM in marine and terrestrial sediments (Volkman et al. 1992; Tolosa et al. 2009). Of these, $n$-alkanes are produced by a broad range of organisms. Moreover, $n$-alkanes are easy to analyse and hence, often used to identify the sources of OM in water, suspended matter and sediments from different environments (Harji et al. 2008; Kameyama et al. 2009; Maioli et al. 2011). This is because the assemblage of $n$-alkanes found in marine biota is different from that found in terrestrial biota. For example, marine planktons such as algae and cyanobacteria exhibit predominance of short chain, odd carbon $n$-alkanes mainly at $\mathrm{C}_{15}, \mathrm{C}_{17}$ and $\mathrm{C}_{19}$

Keywords. Sediments; lipids; $n$-alkanes; Visakhapatnam harbour. 
while terrestrial plants exhibit predominance of long chain, odd carbon $n$-alkanes at $\mathrm{C}_{23}, \mathrm{C}_{25}, \mathrm{C}_{27}$, $\mathrm{C}_{31}$ and $\mathrm{C}_{33}$ (Clark and Blumer 1967; Cranwell 1973; Brassel et al. 1978; Sonibare and Sojinu 2009; Ahad et al. 2011). Similarly, the predominance of short chain, even carbon number $n$ alkanes in the range of $\mathrm{C}_{12}-\mathrm{C}_{22}$ is attributed to micro-organisms including diatoms and petroleum (Grimalt and Albaiges 1987; Garg and Bhosle 2004). Furthermore, indices such as unresolved complex mixture (UCM), carbon preference index (CPI), pristane/phytane, $n$ - $\mathrm{C}_{17} /$ pristane and $n$ $\mathrm{C}_{18} /$ phytane ratios are useful to identify $n$-alkane sources (Volkman et al. 1992; Commendatore and Esteves 2004; Zaghden et al. 2005; Hu et al. 2009).

Visakhapatnam harbour, a semi-enclosed water body is one of the largest and busiest ports of India along the east coast of India. Since the beginning of 1950s, many large scale basic and other major industries were set up by the government and the private sector in its vicinity. The harbour is land-locked and this has resulted in limited natural flushing processes enhancing pollution stress on the harbour (Raman 1995). Studies on biological, chemical and geophysical parameters have indicated the influence of anthropogenic activities on the harbour and also their subsequent effects on the biological community and the ecosystem as a whole (Subbarao and Subbarao 1994; Raman 1995; Sultana and Rao 1998; Harji et al. 2010). Presently, we are studying distribution as well as molecular level characterization of OM in coastal and deep sea sediments. Such studies provide useful information on the nature, sources and cycling of OM. In the present study, we report on the distribution and molecular level characterization of OM. The objectives of this study were formulated to

- assess the distribution of organic carbon (OC), stable carbon isotopes, total lipid (TL) and $n$ alkanes in coastal sediments,

- identify the sources of OM using a combined approach of stable carbon isotopes, and $n$-alkanes,

- get an insight into the contribution of OC from different sources, and

- to assess if the harbour sediments were influenced by petroleum products.

\section{Materials and methods}

\subsection{Description of the sampling area}

Visakhapatnam harbour is located at $17^{\circ} 41^{\prime} 825^{\prime \prime}-$ $17^{\circ} 42^{\prime} 313^{\prime \prime} \mathrm{N}$ and $83^{\circ} 16^{\prime} 881^{\prime \prime}-83^{\circ} 19^{\prime} 793^{\prime \prime} \mathrm{E}$, along the east coast of India (figure 1) at the mouth of a surface drain known as Meghadrigedda. It consists of an inner harbour and an outer harbour. There are 24 berths and 4 moorings to accommodate 28 ships at a time. The effluents of an oil refinery, a steel plant, a fertilizer plant and a lead and zinc smelter in the vicinity are discharged into this harbour. The harbour handles items such as manganese and iron ore, coal and oil products. Added to this, it receives most of the urban run-off and waste water discharge.

\subsection{Cleaning of glassware and solvent purification}

All the glassware was cleansed by washing with tap water, chromic acid and distilled water are heated to $450^{\circ} \mathrm{C}$ for 6 hours. After this, it was rinsed with methanol and dichloromethane. The solvents were of analytical grade and were double distilled before use. Sodium sulphate was ashed at $450^{\circ} \mathrm{C}$ and silicic acid, silica and alumina were washed with methanol and chloroform and dried prior to use.

\subsection{Sample collection and analysis}

Surficial sediment samples (the top 10-15 cm) were collected from various stations along the Visakhapatnam harbour (figure 1) using a VanVeen grab. The samples were frozen onboard and soon transported to the laboratory in an ice box and stored at $-20^{\circ} \mathrm{C}$. The sediment samples were then lyophilized, powdered using agate mortar and pestle and stored at $-20^{\circ} \mathrm{C}$ until analysed. The sediments were then used for the estimation of $\mathrm{OC}, \delta^{13} \mathrm{C}$, TL and $n$-alkane concentration and composition.

\subsection{Estimation of bulk geochemical parameters}

Samples for $\mathrm{OC}$ and $\delta^{13} \mathrm{C}_{\mathrm{oc}}$ analysis were treated with $1 \mathrm{~N} \mathrm{HCl}$, and subsequently washed with distilled water to remove the $\mathrm{HCl}$ traces. The finely decarbonised sediments were packed and loaded onto CNS elemental analyzer (NCS 2500, $\mathrm{CE}$ instruments) for OC analysis. 2, 5-Bis-(5tetrabutyl-benzoxazol-2-yl) thiopen (BBOT) was used as a standard for calibration. For $\delta^{13} \mathrm{C}_{\mathrm{oc}}$ analysis, Thermo Finnigan Flash 1112 elemental analyzer, linked with a Thermo Finnigan Delta V plus Isotope Ratio MS was used. The $\delta^{13} \mathrm{C}$ values are reported in the delta notation relative to Pee Dee Belemnite (PDB) standard. The analytical precision was within $\pm 1.6 \%$ for $\mathrm{OC}$ and $\pm 0.2 \%$ o for $\delta^{13} \mathrm{C}_{\mathrm{oc}}$. All the $\mathrm{OC}$ isotopic compositions are reported in parts per million (\%o) relative to 


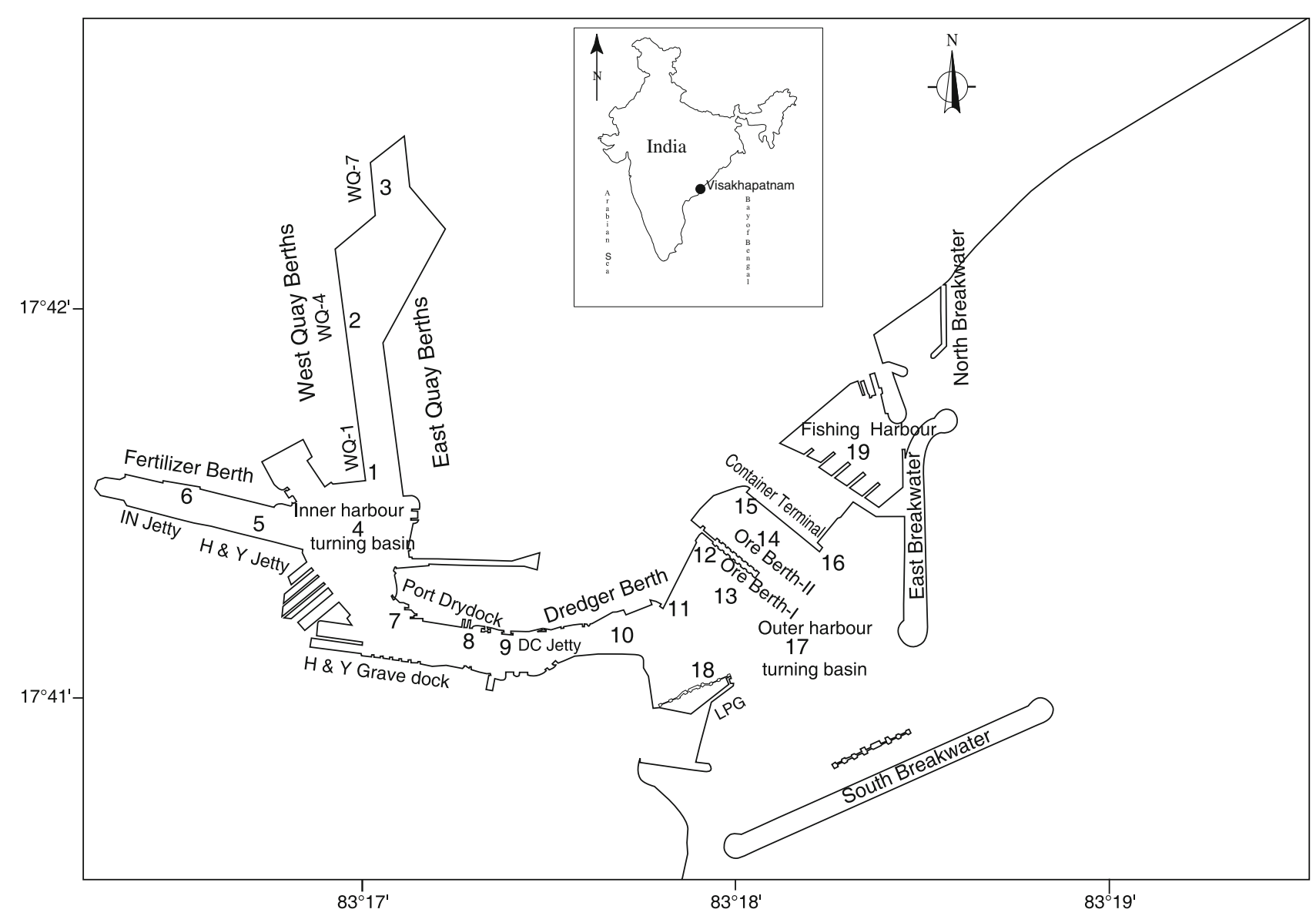

Figure 1. Map of the study area showing sampling stations in the Visakhapatnam harbour, east coast of India.

variation $(\delta)$ from the PDB standard and calculated as follows:

$$
\begin{aligned}
\delta^{13} \mathrm{C}_{\mathrm{OC}}= & \left\{\left({ }^{13} \mathrm{C} /{ }^{12} \mathrm{C}\right)_{\text {Sample }} /\left({ }^{13} \mathrm{C} /{ }^{12} \mathrm{C}\right)_{\mathrm{PDB}}-1\right\} \\
& \times 1000
\end{aligned}
$$

\subsection{Extraction of lipids}

Total lipids (TL) were extracted from lyophilized sediments following the method of Bligh and Dyer (1959) and estimated following Harji et al. (2008). In brief, sediments were shaken vigorously with chloroform:methanol:phosphate buffer (1:2:0.8, V/V/V) and kept standing for $24 \mathrm{~h}$. Separation of the organic phase was achieved after adjusting the ratio of chloroform:methanol:water to 1:1:0.9 in a separating funnel. The extracts were combined, treated with anhydrous sodium sulphate and filtered through Whatman No.1 filter paper. The filtrate was concentrated using a rotary evaporator under reduced pressure and made to a known volume $(1 \mathrm{ml})$. A known aliquot was then put on pre-weighed Whatman filter paper. The paper was dried in a vacuum desiccator and weighed again. The weight of TL was obtained after subtracting the weight of the empty filter paper from the filter paper containing dried lipid extract (Zaghden et al. 2005; Harji et al. 2008). The method showed a standard deviation of $\pm 5.3 \%$ based on replicate analyses.

\subsection{Separation of $n$-alkanes}

Separation of $n$-alkanes from TL was done by silicic acid and silica-alumina column chromatography. Before use, silicic acid was activated for two hours at $120^{\circ} \mathrm{C}$ and packed onto glass column $(10 \times$ $0.5 \mathrm{~cm}$ ). TL was loaded onto the column and eluted with dichloromethane. The neutral lipid fraction thus, obtained, was concentrated at $30^{\circ} \mathrm{C}$ using a rotary evaporator under reduced pressure.

The neutral lipid fraction eluted with dichloromethane was further subjected to silicaalumina column chromatography. Both silica and alumina were activated at $110^{\circ} \mathrm{C}$ overnight and then deactivated with $5 \%$ distilled water before use. The glass column $(10 \times 0.5 \mathrm{~cm})$ was filled with silica and alumina and topped with activated copper powder using hexane. Neutral lipid fraction was loaded onto the column, and $n$-alkanes 
were eluted using $n$-hexane. The $n$-hexane fraction was treated with anhydrous sodium sulphate and reduced to near dryness using a rotary evaporator under reduced pressure. The final volume of the $n$-alkanes was adjusted $(100 \mu \mathrm{L})$ after adding methyl nonadecanoate as the internal standard. A suitable aliquot of the fraction was analysed using the GC and GC-MS.

\section{$2.7 G C$ and $G C-M S$ analysis}

The $n$-alkanes were analysed using GC (Agilent GC model 6890 Plus) equipped with FID and SE52 fused silica capillary column $(30 \mathrm{~m} \times 0.32 \mathrm{~mm}$ i.d $\times 0.25 \mu \mathrm{m}$ film thickness). A sample of $1 \mu \mathrm{l}$ was injected using on-column injector when the injector temperature was maintained at $300^{\circ} \mathrm{C}$. The temperature of the detector was maintained at $325^{\circ} \mathrm{C}$. The carrier gas was nitrogen and the flow rate was

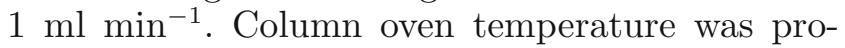
grammed at $80^{\circ} \mathrm{C}$ for $1 \mathrm{~min}$, and then from $80^{\circ}$ to $150^{\circ} \mathrm{C}$ at $6^{\circ} \mathrm{C} \mathrm{min}^{-1}$, and then from $150^{\circ}$ to $280^{\circ} \mathrm{C}$ at $4^{\circ} \mathrm{C} \mathrm{min}^{-1}$ and kept at $280^{\circ} \mathrm{C}$ for $25 \mathrm{~min}$.

The quantification of the $n$-alkanes was done using the data handling system available on the instrument. The $n$-alkanes were identified using authentic standards $\left(n \mathrm{C}_{11}-n \mathrm{C}_{33}\right)$ procured from Supelco, USA. The peak areas were quantified with respect to the internal standard (methyl nonadecanoate). Based on the area of the internal standard and the areas of all $n$-alkanes in the sample, the concentration of UCM was calculated. The sum of the concentrations of the $n$-alkanes and UCM has been defined as total hydrocarbon (THC). The CPI for $n$-alkanes is defined as the ratio of the sum of odd carbon number homologues in a specified range to the sum of even carbon number homologues in the given range (Cranwell 1973; Elias et al. 2000). Recovery of 10 standard $n$-alkanes $\left(\mathrm{C}_{20}-\mathrm{C}_{29}\right)$ varied from 75 to $92 \%(\mathrm{X}=81 \% \pm 7.9)$. Standard deviation for the method was within $15 \%$ based on replicate analysis. Solvents were passed through the entire analytical procedure and were used as blank.

Verification of the $n$-alkane peaks as well as determination of hopanes and steranes were done on GC-MS Shimadzu QP 2010. Capillary column RTX-5MS $(30 \mathrm{~m} \times 0.32 \mathrm{~mm}$ i.d $\times 0.25 \mu \mathrm{m}$ film thickness) was used. Injector temperature was $60^{\circ} \mathrm{C}$ and source housing temperature was maintained at $250^{\circ} \mathrm{C}$. Carrier gas used was helium and flow rate was maintained at $1.5 \mathrm{ml} \mathrm{min}{ }^{-1}$. Sample of $1 \mu \mathrm{l}$ was injected using an on-column injector. Oven temperature was programmed to rise from $80^{\circ}$ to $120^{\circ} \mathrm{C}$ at a ramped rate of $30^{\circ} \mathrm{C} \mathrm{min}{ }^{-1}$, then from $120^{\circ}$ to $320^{\circ} \mathrm{C}$ at a ramped rate of $4^{\circ} \mathrm{C}$ $\min ^{-1}$ and kept at this temperature for $15 \mathrm{~min}$. GC-MS operation was in full scan mode, scanning from $m / z 50$ to $m / z 500$. Detection of hopanes and steranes was done using ions at $m / z 191$ and $m / z$ 217, respectively (Zaghden et al. 2005; Harji et al. 2008).

\subsection{Statistical analysis}

A simple correlation was used to assess relationship between different parameters using Microsoft Excel program.

\section{Results and discussion}

\subsection{Bulk parameters}

The distribution of $\mathrm{OC}, \delta^{13} \mathrm{C}_{\mathrm{oc}}$ and TL are presented in table 1 . OC ranged from $0.6 \%$ (station 4 ) to $7.6 \%$ (station 5 ). OC values are comparable to those which have been reported from other coastal regions (Harji et al. 2008 and references therein). The $\delta^{13} \mathrm{C}_{\mathrm{oc}}$ values in the Visakhapatnam harbour varied from $-29.3 \%$ to $-23.8 \%$. Highly depleted value $(-29.3 \%)$ was observed at station 17 while relatively enriched value $(-23.8 \%$ ) was observed at station 19. The $\delta^{13} \mathrm{C}_{\text {oc }}$ values for marine $\mathrm{OM}$ have been reported to be in the range of -21 to $-19 \%$ while for terrestrial plants with C3 pathway, it is in the range of -33 to $-22 \%$ (Fry and Sherr 1984; Pancost and Boot 2004). Our $\delta^{13} \mathrm{C}_{\mathrm{oc}}$ values

Table 1. Geochemical data for surficial sediments from Visakhapatnam harbour, east coast of India.

\begin{tabular}{|c|c|c|c|c|c|c|}
\hline \multirow{2}{*}{$\begin{array}{l}\text { Station } \\
\text { no. }\end{array}$} & \multirow{2}{*}{$\begin{array}{c}\mathrm{OC} \\
\%\end{array}$} & \multirow{2}{*}{$\begin{array}{c}\delta 13 \mathrm{C}_{\mathrm{oc}} \\
\% 0\end{array}$} & TL & T Alk & THC & UCM \\
\hline & & & \multicolumn{4}{|c|}{$\left(\mu \mathrm{g} \mathrm{g}{ }^{-1} \mathrm{dw}\right)$} \\
\hline$\# 1$ & 1 & -25.4 & 4200 & 11 & 344 & 332 \\
\hline$\# 2$ & - & - & 4050 & 23 & 550 & 519 \\
\hline$\# 3$ & 6.7 & -26.1 & 1528 & 19 & 847 & 822 \\
\hline$\# 4$ & 0.6 & -26.1 & 1575 & 8 & 166 & 157 \\
\hline$\# 5$ & 7.6 & -26.3 & 14,948 & 31 & 327 & 295 \\
\hline$\# 6$ & 7.4 & -29.2 & 6900 & 18 & 2277 & 2244 \\
\hline$\# 7$ & 4 & -24.6 & 4083 & 16 & 860 & 843 \\
\hline$\# 8$ & 1.9 & -27.4 & 5400 & 7 & 457 & 446 \\
\hline$\# 9$ & 2.4 & -28.1 & 900 & 9 & 386 & 372 \\
\hline \#10 & - & - & 2724 & 23 & 318 & 291 \\
\hline \#11 & 2.7 & -26.8 & 600 & 13 & 13 & nd \\
\hline$\# 12$ & 4.4 & -27 & 1575 & 8 & 195 & 185 \\
\hline \#13 & 4.1 & -24.4 & 2550 & 6 & 258 & 252 \\
\hline$\# 14$ & 1.3 & -25.1 & 300 & 2 & 2 & nd \\
\hline \#15 & - & -26.9 & 2600 & 10 & 11 & nd \\
\hline \#16 & 3 & -25.8 & 2250 & 5 & 5 & nd \\
\hline$\# 17$ & 0.7 & -29.3 & 300 & 0.2 & 0.2 & nd \\
\hline \#18 & 1.2 & -24.9 & 1718 & 0.4 & 1 & nd \\
\hline \#19 & 1.3 & -23.8 & 3825 & 11 & 948 & 933 \\
\hline
\end{tabular}

OC: Organic carbon, TL: total lipid, $\mathrm{T}$ Alk: total alkane, THC: total hydrocarbon, UCM: unresolved complex mixture. 


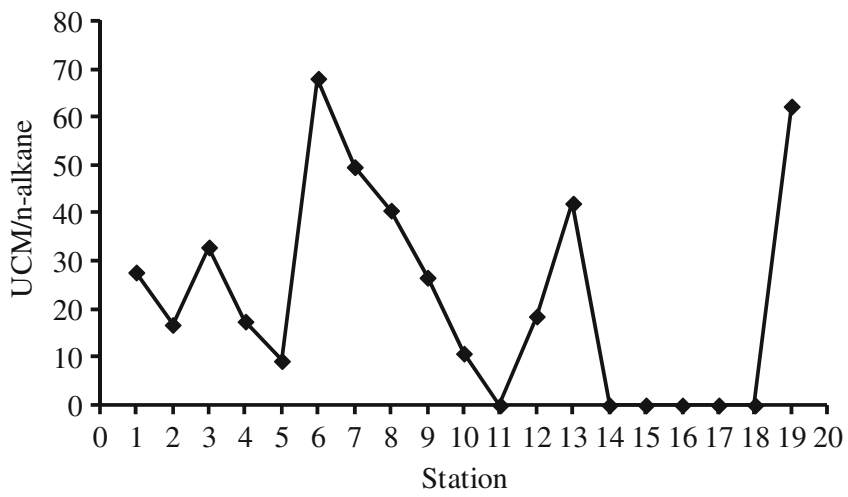

Figure 2. Spatial trend of $\mathrm{UCM} / n$-alkane along the Visakhapatnam harbour, east coast of India.

for the harbour sediments indicate that $\mathrm{OM}$ was derived from both marine and terrestrial C3 plant sources. TL ranged from 300 (stations 14 and 17) to $14,948 \mu \mathrm{g} \mathrm{g} \mathrm{g}^{-1} \mathrm{dw}$ (station 5). These TL values are in the range of values reported earlier for coastal sediments (Harji et al. 2008). Significant correlation was observed between OC and TL $(R=0.710$, $n=14, p<0.01$ ), suggesting common origin for these compounds.

\subsection{Concentrations of THC, total $n$-alkanes and UCM}

The distribution of THC, total $n$-alkanes and UCM is shown in table 1. Concentrations of THC ranged from 0.2 (station 17) to $2277 \mu \mathrm{g} \mathrm{g} \mathrm{g}^{-1} \mathrm{dw}$ (station 6 ). The concentrations of THC observed for the Visakhapatnam harbour sediments are comparable to those reported from other coastal areas (Mille et al. 2007; Harji et al. 2008). THC showed a significant positive correlation with OC $(R=0.762$, $n=14, p<0.001)$, suggesting that THC was an important contributor to the OC. Sediments are considered as unpolluted, if the THC concentration is below $10 \mu \mathrm{g} \mathrm{g}^{-1} \mathrm{dw}$ (Farrington and Tripp 1977; Volkman et al. 1992; Readman et al. 2002). In our study, out of the 19 stations, 14 stations (stations $1,2,3,4,5,6,7,8,9,10,12,13,14$ and 19) showed values $>10 \mu \mathrm{g} \mathrm{g}^{-1} \mathrm{dw}$, indicating that these stations were contaminated with petroleum input.

The total $n$-alkanes ranged from 0.2 (station 17) to $31 \mu \mathrm{g} \mathrm{g}{ }^{-1} \mathrm{dw}$ (station 5) (table 1). Concentrations of $n$-alkanes were relatively higher at stations 2, 3, 5, 6 and 10 than those observed at other stations. The concentrations of total $n$ alkanes recorded in the present study are comparable to those reported earlier for other coastal regions. For example, Harji et al. (2008) reported total $n$-alkanes in the range of 1.6 to $10.7 \mu \mathrm{g}$ $\mathrm{g}^{-1} \mathrm{dw}$ from the sediments of Marmugoa harbour while Wagener et al. (2012) reported in the range of 7.66 to $57.22 \mu \mathrm{g} \mathrm{g}^{-1} \mathrm{dw}$ from the sediments of Guanabara Bay.

The concentrations of the UCM ranged from 157 (station 4) to $2244 \mu \mathrm{g} \mathrm{g}^{-1} \mathrm{dw}$ (station 6). UCM is a mixture of structurally complex isomers of homologous branched/cyclic hydrocarbons that cannot be resolved by capillary GC columns (Bouloubassi and Saliot 1993; Readman et al. 2002; Gao et al. 2007). In general, the presence of UCM is indicative of degraded/weathered petroleum contamination although, bacterial reworking of $\mathrm{OM}$ cannot be ruled out (Farrington and Tripp 1977; Volkman et al. 1992; Hu et al. 2009). UCM was observed at stations $1,2,3,4,5,6,7,8,9,10,12,13$ and 19. A weathering index expressed as the ratio of

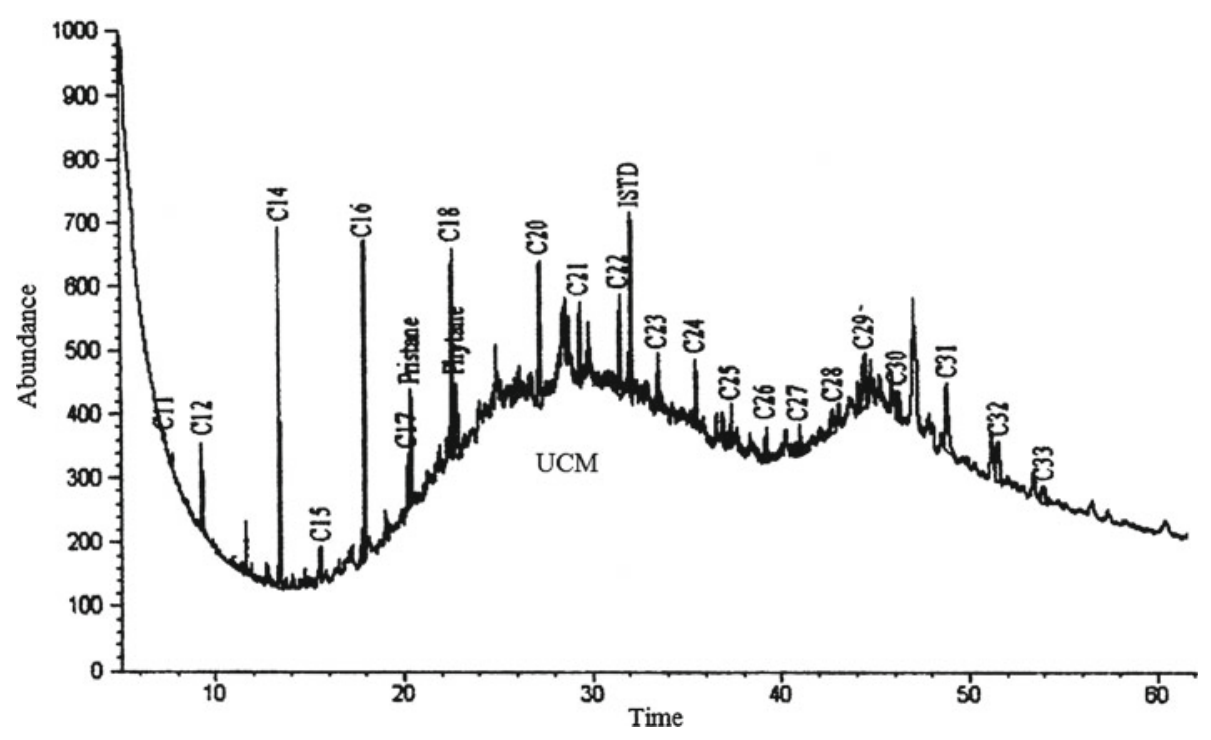

Figure 3. A representative gas chromatogram profile of $n$-alkanes at station 3 in the Visakhapatnam harbour, east coast of India. 


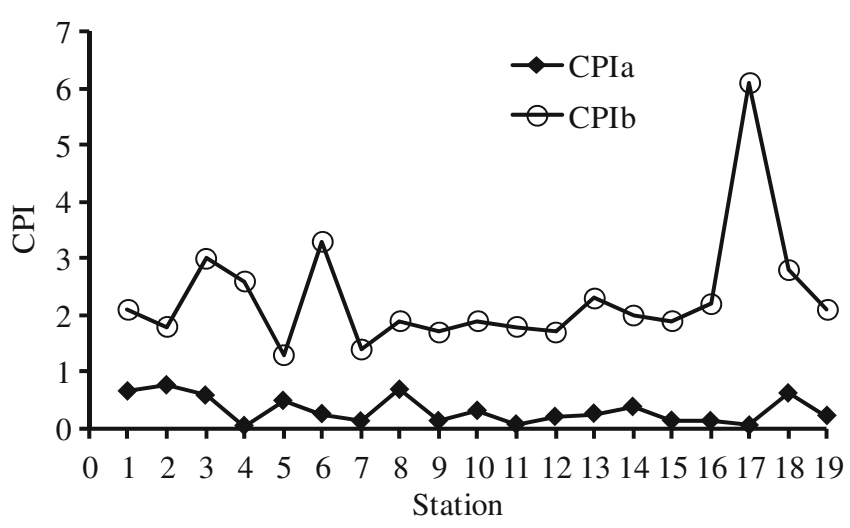

Figure 4. Spatial variation of CPI (carbon preference index) in surface sediments of Visakhapatnam harbour, east coast of India. $\mathrm{CPI}^{\mathrm{a}}=\left(n-\mathrm{C}_{11}+n-\mathrm{C}_{13}+n-\mathrm{C}_{15}+n-\mathrm{C}_{17}+n-\mathrm{C}_{19}+n\right.$ $\left.\mathrm{C}_{21}\right) /\left(n-\mathrm{C}_{12}+n-\mathrm{C}_{14}+n-\mathrm{C}_{16}+n-\mathrm{C}_{18}+n-\mathrm{C}_{20}\right) ; \mathrm{CPI}^{\mathrm{b}}=(n-$ $\left.\mathrm{C}_{23}+n-\mathrm{C}_{25}+n-\mathrm{C}_{27}+n-\mathrm{C}_{29}+n-\mathrm{C}_{31}\right) /\left(n-\mathrm{C}_{22}+n-\mathrm{C}_{24}+\right.$ $\left.n-\mathrm{C}_{26}+n-\mathrm{C}_{28}+n-\mathrm{C}_{30}+n-\mathrm{C}_{32}\right)$.
$\mathrm{UCM}$ to resolved $n$-alkanes $(\mathrm{U} / \mathrm{R})$ is used as a diagnostic criterion for petroleum pollution. Values $>4$ occur when there is widespread petroleum contamination (Mazurek and Simoneit 1984; Readman et al. 2002). In our study, the $\mathrm{U} / \mathrm{R}$ ratio was high $(>4)$ for all the UCM contaminated stations (figure 2). This suggests a strong influence of petroleum inputs on the sediments of the harbour.

\subsection{Composition of n-alkanes}

The $n$-alkanes ranging from $\mathrm{C}_{11}$ to $\mathrm{C}_{33}$ were observed in the surface sediments of the Visakhapatnam harbour. The distribution of short chain $n$-alkanes $\left(\mathrm{C}_{11}\right.$ to $\left.\mathrm{C}_{22}\right)$ demonstrated the predominance of even carbon $n$-alkanes $\mathrm{C}_{12}, \mathrm{C}_{14}, \mathrm{C}_{16}, \mathrm{C}_{18}$ and $\mathrm{C}_{20}$ (figure 3 ). The predominance of these short chain even $n$-alkanes indicates the contribution of marine microorganisms and petroleum products to the OM of surface sediments of the harbour (Grimalt and Albaiges 1987; Garg and Bhosle 2004; Harji et al. 2008). Similarly, at some stations abundance of short chain odd $n$-alkanes such as

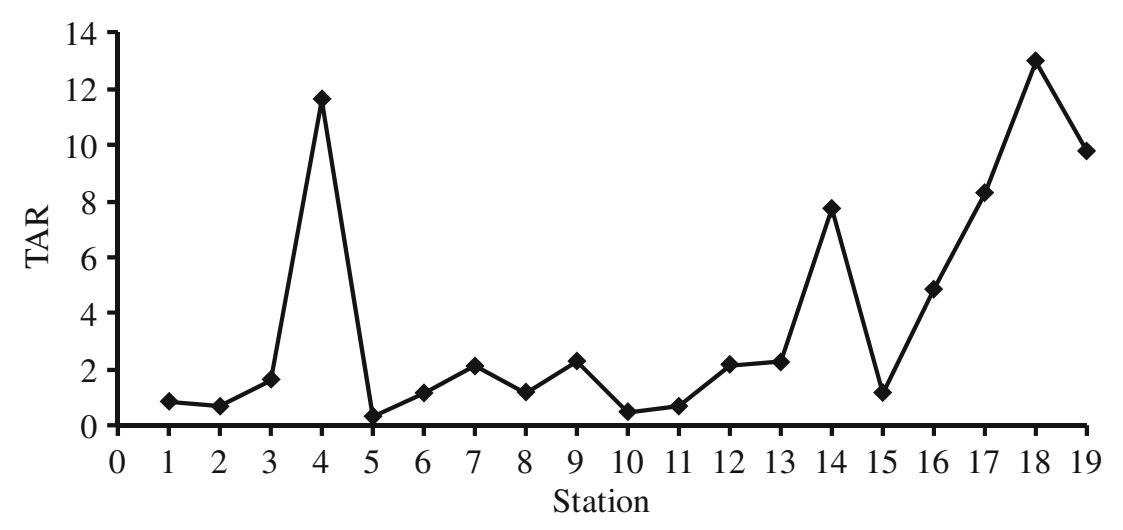

Figure 5. Spatial trend of TAR (terrigenous aquatic ratio) in the surface sediments of Visakhapatnam harbour, east coast of India.

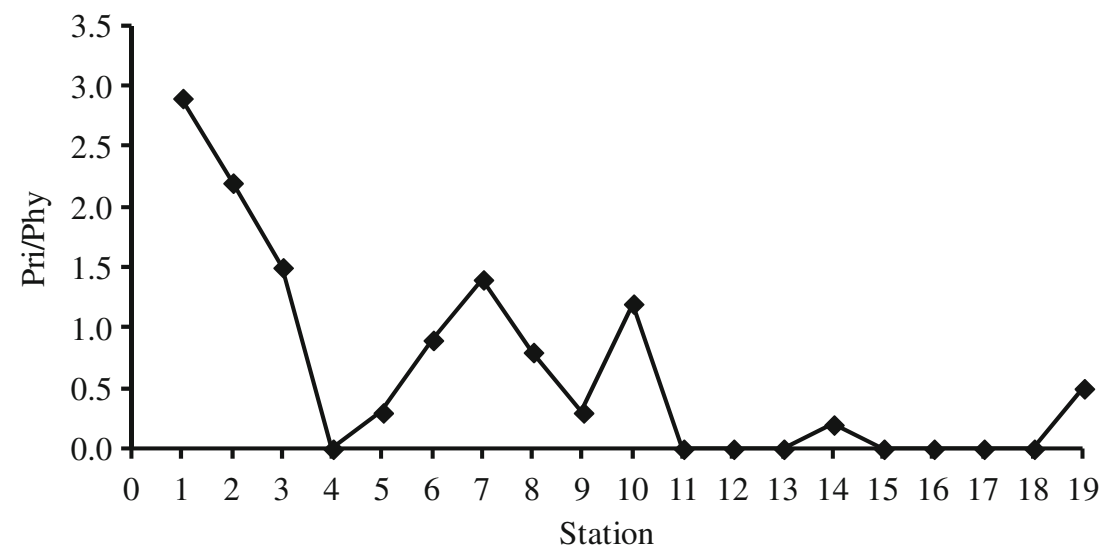

Figure 6. Spatial trend of Pri/Phy (pristane/phytane) in the surface sediments of Visakhapatnam harbour, east coast of India. 


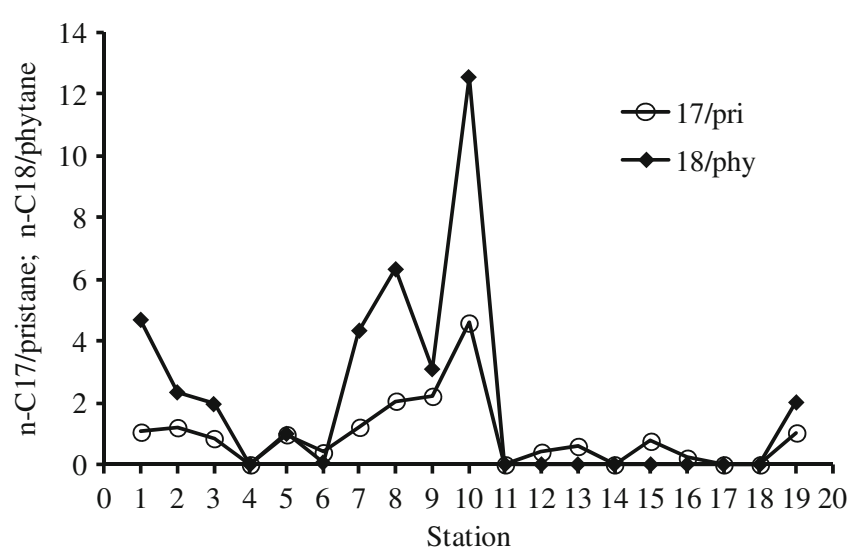

Figure 7. Spatial variation of $n$ - $\mathrm{C}_{17} /$ pristane and $n$ $\mathrm{C}_{18} /$ phytane in the Visakhapatnam harbour, east coast of India.

$\mathrm{C}_{15}, \mathrm{C}_{17}$ and $\mathrm{C}_{19}$ was recorded. Short chain odd $n$-alkanes $\mathrm{C}_{15}, \mathrm{C}_{17}$ and $\mathrm{C}_{19}$ are produced by phytoplankton (Clark and Blumer 1967; Cranwell 1973; Pearson and Eglington 2000; Sonibare and Sojinu 2009). Therefore, the presence of these short chain odd carbon $n$-alkanes indicates the contribution from marine phytoplankton. The long chain odd carbon $n$-alkanes such as $\mathrm{C}_{23}, \mathrm{C}_{25}, \mathrm{C}_{27}, \mathrm{C}_{29}, \mathrm{C}_{31}$ and $\mathrm{C}_{33}$ were also present at some stations. These long chain odd carbon $n$-alkanes are derived from terrestrial plants (Clark and Blumer 1967; Cranwell 1973; Pearson and Eglington 2000; Sonibare and Sojinu 2009).

To further assess the possible sources of $n$ alkanes in the sediments of the Visakhapatnam harbour, CPI was calculated. CPI is a measure of homologous odd over even $n$-alkanes in a specified range of carbon numbers and is routinely used as a source indicator in marine sediments. The CPI (i.e., $\mathrm{C}_{11}+\mathrm{C}_{13}+\mathrm{C}_{15}+\mathrm{C}_{17}+\mathrm{C}_{19}+\mathrm{C}_{21} / \mathrm{C}_{12}+\mathrm{C}_{14}+\mathrm{C}_{16}+\mathrm{C}_{18}+$ $\left.\mathrm{C}_{20}+\mathrm{C}_{22}\right)$ for the short chain $n$-alkanes is designated as $\mathrm{CPI}^{\mathrm{a}}$. The $\mathrm{CPI}^{\mathrm{a}}$ values of 1 or near 1 indicate inputs from petroleum products, whereas $<1$ indicates inputs from microorganisms including bacteria and diatioms (Clark and Blumer 1967; Garg and Bhosle 2004; Ahad et al. 2011). Stations $1,2,3,8$ and 18 exhibited values close to 1 indicating petrogenic inputs. Lower $\mathrm{CPI}^{\mathrm{a}}$ values $(0.1-0.5)$ were observed at stations $4,5,6,7,9,10,11,12,13$, $14,15,16,17$ and 19, suggesting algal and bacterial sources at these stations (figure 4 ). The CPI (i.e., $\mathrm{C}_{23}+\mathrm{C}_{25}+\mathrm{C}_{27}+\mathrm{C}_{29}+\mathrm{C}_{31}+\mathrm{C}_{33} / \mathrm{C}_{24}+\mathrm{C}_{26}+\mathrm{C}_{28}+\mathrm{C}_{30}+$ $\left.\mathrm{C}_{32}\right)$ for the long chain $n$-alkanes $\left(\mathrm{C}_{23-} \mathrm{C}_{33}\right)$ is designated as $\mathrm{CPI}^{\mathrm{b}}$. The $\mathrm{CPI}^{\mathrm{b}}$ values varied between 3 and 20 for higher vascular plants (Brassel et al. 1978; Wang and Fingas 2003). Our CPI $^{\mathrm{b}}$ values varied from 1.3 to 6.1. At stations 3, 4, 6, 17 and 18 , the $\mathrm{CPI}^{\mathrm{b}}$ values indicate the influence of terrestrial OM (figure 4).

In order to evaluate the relative distribution of terrestrial $\mathrm{OM}$ and aquatic algae at the sampled stations, the terrigenous-aquatic ratio (TAR) was calculated (Bourbonniere and Meyers 1996; Peters et al. 2005; Mille et al. 2007). TAR was calculated as follows:

$$
\mathrm{TAR}=\left(\mathrm{C}_{27}+\mathrm{C}_{29}+\mathrm{C}_{31}\right) /\left(\mathrm{C}_{15}+\mathrm{C}_{17}+\mathrm{C}_{19}\right) .
$$

The ratio is $>1$ for terrestrial input and $<1$ for algal input (Bourbonniere and Meyers 1996). Our values ranged from 0.3 to 13 (figure 5 ). The values were $>1$ at stations $3,4,6,7,8,9,10,12,13,14,15$, $16,17,18$ and 19 indicating higher terrestrial input over marine algae at these stations. However, the dominance of long chain $n$-alkanes could be overestimated considering the preferential utilization of labile, short chain $n$-alkanes (Peters et al. 2005; Hu et al. 2009).

Contamination by petroleum-related products can be further assessed with the help of pristane and phytane. Pristane and phytane are isoprenoid hydrocarbons originating from geologic alteration

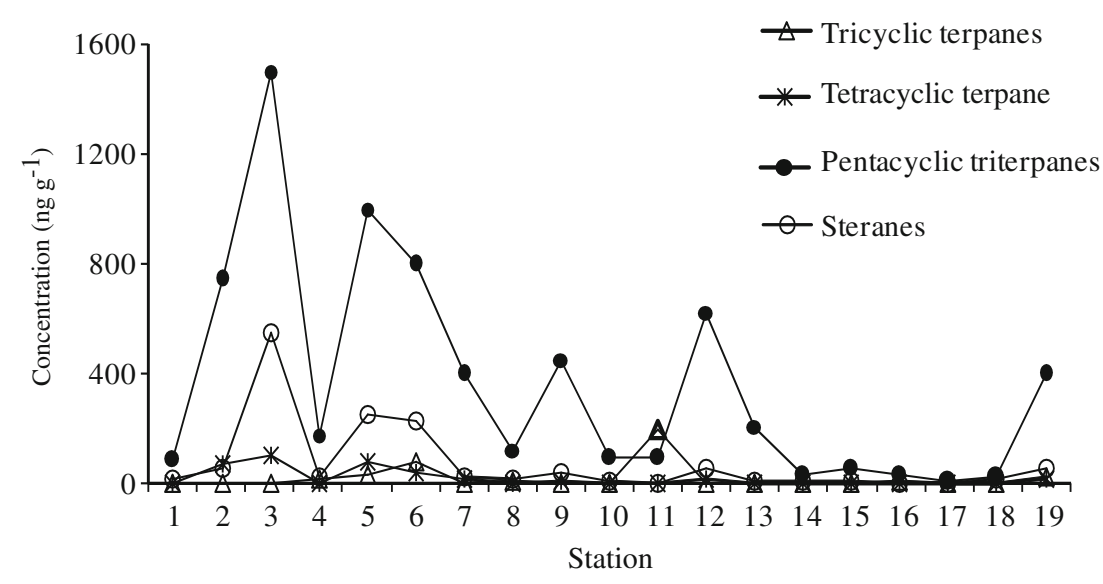

Figure 8. Distribution of tricyclic terpanes, tetracyclic terpanes, pentacyclic triterpanes and steranes in the Visakhapatnam harbour, east coast of India. 
of phytol and other isoprenoidyl products and are not primary constituents of most terrestrial biota (Peters and Moldowan 1993; Gao et al. 2007). They are usually present in most petroleum as major constituents and are considered as good indicators of petroleum contamination (Volkman and Maxwell 1986; Readman et al. 2002; Zaghden et al.
2005). However, in marine environments, pristane can also be derived from zooplanktons and other marine animals while phytane can be contributed by methanogenic and photosynthetic bacteria (Volkman et al. 1992; Le Dreau et al. 1997). In the present study, pristane/phytane ratio varied from 0 to 2.9 (figure 6). For uncontaminated site,

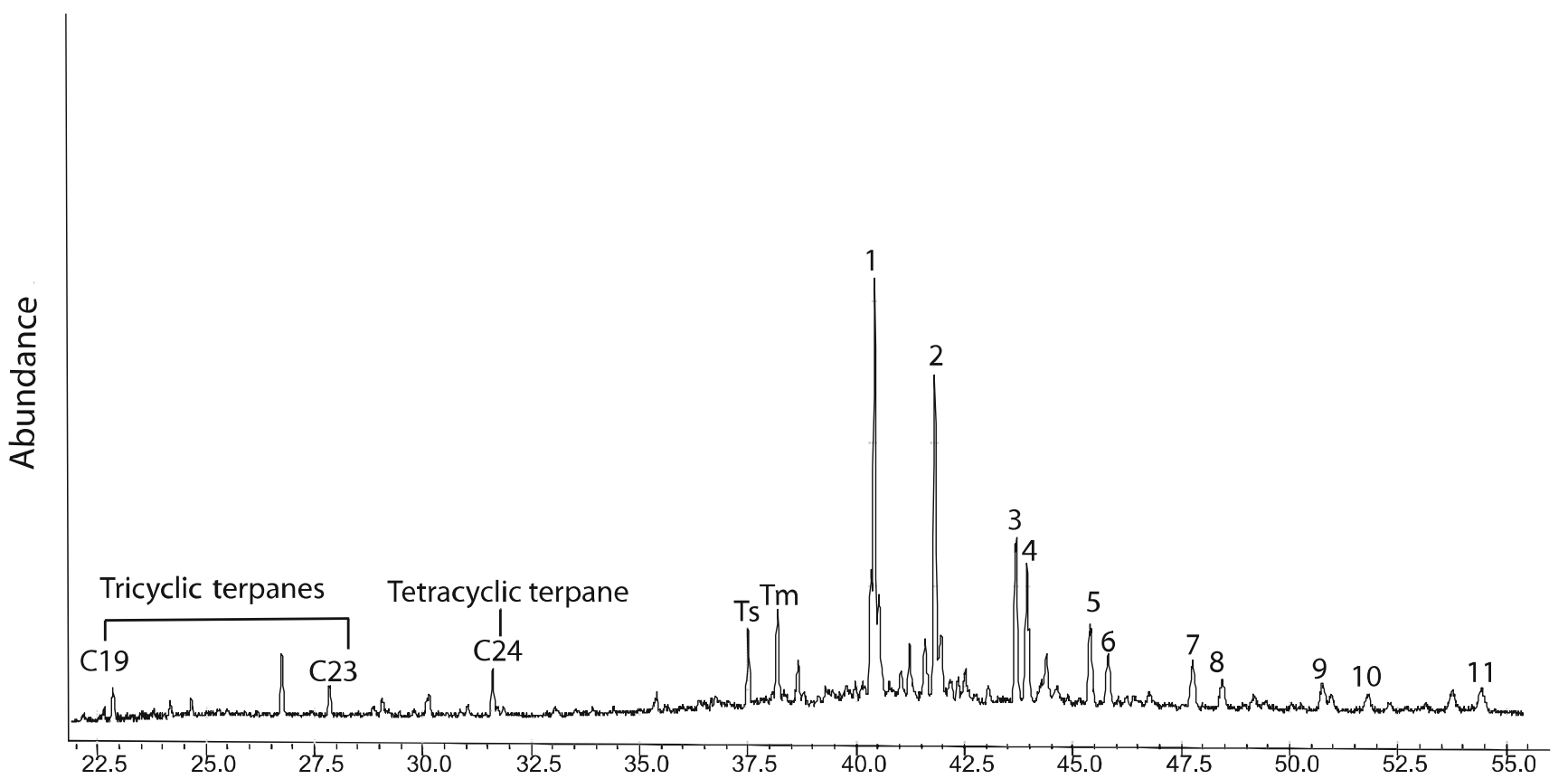

(a)

Time

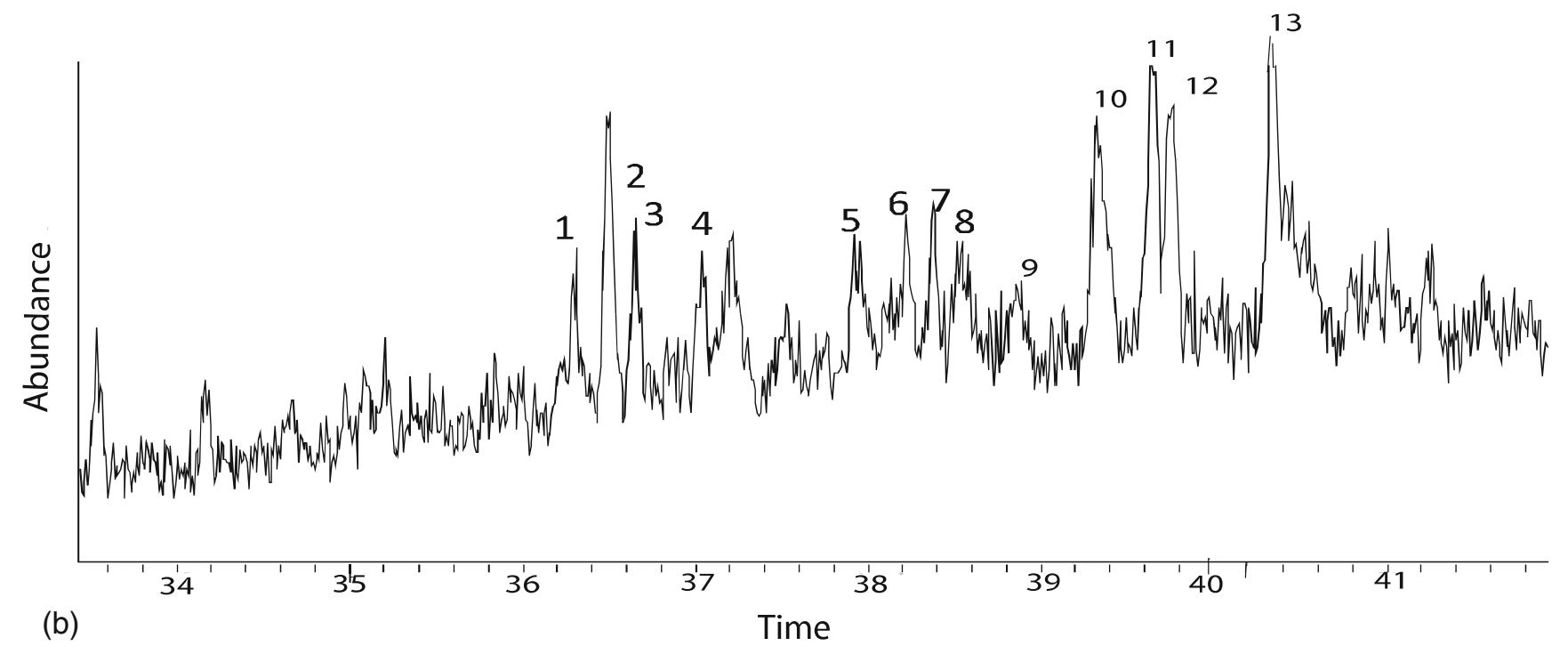

Figure 9. (a) Mass fragmentograms of $m / z 191$ (hopanes) at station 3 in the surface sediments of Visakhapatnam harbour, east coast of India. Ts: $18 \alpha(\mathrm{H})-22,29,30$-trisnorneohopane; Tm: $17 \alpha(\mathrm{H})-22,29,30$-trisnorhopane; $1: 17 \alpha(\mathrm{H}), 21 \beta(\mathrm{H})$ 30-Norhopane; $2: 17 \alpha(\mathrm{H}), 21 \beta(\mathrm{H})$-Hopane; 3: $17 \alpha(\mathrm{H}), 21 \beta(\mathrm{H})$-30-homohopane $(22 \mathrm{~S}) ; 4$ : $17 \alpha(\mathrm{H}), 21 \beta(\mathrm{H})$-30-homohopane $(22 \mathrm{R})$; 5: $17 \alpha(\mathrm{H}), 21 \beta(\mathrm{H})-30,31$-bishomohopane $(22 \mathrm{~S}) ; 6: 17 \alpha(\mathrm{H}), 21 \beta(\mathrm{H})-30,31$-bishomohopane $(22 \mathrm{R}) ; 7: 17 \alpha(\mathrm{H}), 21 \beta(\mathrm{H})-30,31,32-$ trishomohopane $(22 \mathrm{~S}) ; 8: 17 \alpha(\mathrm{H}), 21 \beta(\mathrm{H})-30,31,32$-trishomohopane $(22 \mathrm{R}) ; 9: 17 \alpha(\mathrm{H}), 21 \beta(\mathrm{H})$-30,31,32,33-tetrakishomohopane $(22 \mathrm{~S}) ; 10: 8-17 \alpha(\mathrm{H}), 21 \beta(\mathrm{H})-30,31,32,33$-tetrakishomohopane; 11: $17 \alpha(\mathrm{H}), 21 \beta(\mathrm{H})$-pentakishomohopane (22S). (b). Mass fragmentograms of $m / z 217$ (Steranes) in the surface sediments of Visakhapatnam harbour, east coast of India. 1: 27 $\alpha \alpha \alpha$ (S); 2: $27 \alpha \beta \beta(\mathrm{R}) ; 3: 27 \alpha \beta \beta(\mathrm{S}) ; 4: 27 \alpha \alpha \alpha(\mathrm{R}) ; 5: 28 \alpha \alpha \alpha(\mathrm{S}) ; 6: 28 \alpha \beta \beta(\mathrm{R}) ; 7: 28 \alpha \beta \beta(\mathrm{S}) ; 8: 28 \alpha \alpha \alpha(\mathrm{R}) ; 9: 29 \alpha \alpha \alpha(\mathrm{S}) ; 10$ : $29 \alpha \beta \beta(\mathrm{R}) ; 11: 29 \alpha \beta \beta(\mathrm{S}) ; 12: 29 \alpha \alpha \alpha(\mathrm{R}) ;(\alpha \alpha \alpha=5 \alpha(\mathrm{H}), 14 \alpha(\mathrm{H}), 17 \alpha(\mathrm{H})$-steranes; $\alpha \beta \beta=5 \alpha(\mathrm{H}), 14 \beta(\mathrm{H}), 17 \beta(\mathrm{H})$-steranes. $\mathrm{R}$ and $\mathrm{S}=\mathrm{R}$ and $\mathrm{S}$ at $\mathrm{C}-20$ configuration). 
pristane/phytane ratio varies from 3-5 whereas for petroleum contaminated sites the ratio is $\leq 1$ (Zaghden et al. 2005; Gao et al. 2007). The values were $\leq 1$ at stations $5,6,7,8,9,10,14$ and 19 indicating petroleum input at these sites.

Further, $n$ - $\mathrm{C}_{17} /$ pristane and $n$ - $\mathrm{C}_{18} /$ phytane ratios are used to evaluate the presence of freshly derived and degraded petroleum hydrocarbons in the sediments (Commendatore and Esteves 2004; Harji et al. 2008). The value is $<1$ for degraded petroleum and $>1$ for fresh petroleum input (UNEP 1995; Harji et al. 2008). In our study, the $n-\mathrm{C}_{17} /$ pristane values ranged from 0.2 to 4.6 (figure 7 ). The ratios indicated that fresh petroleum input was present at stations 1, 2, 3, 7, 8, 9 and 10 whereas, degraded petroleum was observed at stations $6,12,13,14,15,16$ and 18 . This was further supported by the $n$ - $\mathrm{C}_{18} /$ phytane ratios which ranged from 0.1 to 12.5 (figure 7 ).

\subsection{Hopanes and steranes}

The presence of petroleum compounds was substantiated by the presence of hopanes and steranes. Hopanes and steranes are resistant to environmental alteration and are routinely used to fingerprint petroleum contamination in sediments (Volkman 1986; Peters and Moldowan 1993; Zaghden et al. 2005; Harji et al. 2008; Hu et al. 2009). Hopanes (8-1602 $\mathrm{ng} \mathrm{g}^{-1}$ in stations 17 and 3, respectively) and steranes $\left(0-554 \mathrm{ng} \mathrm{g}^{-1}\right.$ in stations 17 and 3 , respectively) were detected at the study site (figure 8). Ion chromatograms for hopanes $(\mathrm{m} / \mathrm{z}$ 191) showed the presence of tricyclic and tetracyclic terpanes and pentacyclic triterpanes (figure 9a). Of the total hopanes present, pentacyclic triterpanes accounted for $96 \%$ and tetracyclic and tricyclic terpanes together constituted $4 \%$. Of this, the presence of $17 \alpha(\mathrm{H}), 21 \beta(\mathrm{H})$ configuration $(47 \%)$ and $18(\mathrm{H})-22,29,30$-trisnorneohopane (5\%) strongly supports the presence of petroleum compounds (Shi et al. 2008). High concentrations of these compounds were observed at stations 2 , $3,5,6,7,9,12,13$ and 19. Tetracyclic and tricyclic terpanes are found in crude oil and fossil fuel, respectively (Moldowan and Seifert 1983; Aboul-Kassim and Simoneit 1996; Sanchez and Permanyer 2006). These were detected at stations $3,5,6,12$ and 19. The mass fragmentograms of steranes $(m / z 217)$ reveal the presence of $\mathrm{C}_{27}$ and $\mathrm{C}_{28}$ cholestane and $\mathrm{C}_{29}$ stigmastane with their $20 \mathrm{~S}$ and 20R epimers (figure $9 \mathrm{~b}$ ). Steranes are strong indicators of petroleum input as they are absent in unpolluted recent surface sediments (Mackenzie et al. 1982). In this study, steranes were detected in varying concentrations in all the stations except for station 17. Elevated concentration of steranes was observed at stations $2,3,5,6,7,9,12$, and 19 .
Major steranes detected in the study site were $\mathrm{C}_{29}$ stigmastane (54\%) followed by $\mathrm{C}_{27}(26 \%)$ and $\mathrm{C}_{28}$ steranes (20\%) with their 20S and 20R epimers. The composition of $\mathrm{C}_{27}-\mathrm{C}_{29}$ steranes indicates a mixed source of origin of the constituent oils. Generally, $\mathrm{C}_{29}$ steranes indicate petroleum input derived from terrestrial sources while $\mathrm{C}_{27}$ steranes are derived from marine sources (Volkman 1986; Peters and Moldowan 1993; Gao et al. 2007). The dominance of $\mathrm{C}_{29}$ steranes in the present study indicates terrestrial source of origin of petroleum. Earlier studies had attributed the dominance of $\mathrm{C}_{29}$ steranes in sediments to be typical of nonmarine crude oil ( $\mathrm{Hu}$ et al. 2009; Bouloubassi et al. 2001). However, it is also known that higher abundance of $\mathrm{C}_{29}$ steranes could possibly indicate microbial activity in the host environment as $\mathrm{C}_{27}$ and $\mathrm{C}_{28}$ steranes are more susceptible to microbial degradation (Ollivier and Magot 2005). Hence, the abundance of $\mathrm{C}_{28}$ steranes in the study site due to microbial activity cannot be ruled out.

\section{Conclusion}

In summary, the geochemical parameters and $n$ alkane distribution in Visakhapatnam harbour sediments indicate that the harbour sediments were influenced by a mixed contribution from terrestrial and marine sources. The $n$-alkane distribution indicates that the $\mathrm{OM}$ in the harbour is mainly contributed by microbial activity and petroleum products followed by terrestrial sources of input. The contribution of marine phytoplankton, though minimal, was observed. This was further supported by the carbon preference index (CPI) and terrigenous-aquatic ratio (TAR) and unresolved complex mixture (UCM) $/ n$-alkane ratio. The presence of high UCM is also a positive indicator of weathered oil residues. This was further substantiated by $n-\mathrm{C}_{17} /$ pristane and $n-\mathrm{C}_{18} /$ phytane ratios. The compositional pattern of hopanes and steranes strongly indicate that the harbour is contaminated by petroleum related compounds. This study may be used as baseline information in future source studies of OM from $n$-alkanes and may help in mitigating incongruities between source allocations and the magnitudes of prospective sources.

\section{Acknowledgements}

The authors acknowledge Dr Satish R Shetye, the Director of National Institute of Oceanography, for facility and encouragement. They are thankful to the European Commission for partial financial support (EC contract No. P1510658) under project 
'Assesing impacts of TBT on different coastal uses'. VRP thanks UGC-CSIR, New Delhi for Research Fellowship. RRH also acknowledges CSIR-HRD, New Delhi for the fellowship. This is NIO contribution 5259 .

\section{References}

Aboul-Kassim T A T and Simoneit B R T 1996 Lipid geochemistry of surficial sediments from the coastal environment of Egypt 1. Aliphatic hydrocarbons - characterization and sources; Mar. Chem. 54 135-158.

Ahad J M E, Ganeshram R S, Bryant C L, CisnerosDozale L M, Ascough P L, Fallick A E and Slater G L 2011 Sources of $n$-alkanes in an urbanized estuary: Insights from molecular distributions and compoundspecific stable and radiocarbon isotopes; Mar. Chem. 126 $1-4$.

Bligh E G and Dyer W J 1959 A rapid method of total lipid extraction and purification; Can. J. Biochem. Physiol. 37 911-917.

Bouloubassi I and Saliot A 1993 Investigation of anthropogenic and natural organic inputs in estuarine sediments using hydrocarbon markers (NAH, LAB, PAH); Oceanol. Acta 16 145-161.

Bouloubassi I, Fillaux J and Saliot A 2001 Hydrocarbons in the surface sediments from the Changjiang (Yangtze River) Estuary, East China Sea; Mar. Pollut. Bull. 42 1335-1346.

Bourbonniere R A and Meyers P A 1996 Sedimentary geolipid records of historical changes in the watersheds and productivities of Lake Ontario and Erie; Limnol. Oceanogr. 41 352-359.

Brassel S C, Eglington G, Maxwell J R and Philp R P 1978 Natural background of alkanes in the aquatic environment; In: Aquatic Pollutants: Transformation and Biological Effects (eds) Hutzinger O, van Lelyveld L $\mathrm{H}$ and Zoeteman B C J (Oxford, England: Permagon Press), pp. 69-86.

Clark R C Jr and Blumer M 1967 Distribution of $n$-paraffins in marine organisms and sediment; Limnol. Oceanogr. 12 79-87.

Cranwell P A 1973 Chain length distribution of $n$-alkanes from lake sedeimnts in relation to post glacial environment change; Freshwater Biol. 3 259-265.

Commendatore M G and Esteves J L 2004 Natural and anthropogenic hydrocarbons in sediments from the Chubut River (Patagonia, Argentina); Mar. Pollut. Bull. 48 910-918.

Elias V O, Cardoso J N and Simoneit B R T 2000 Acyclic lipids in Amazon Shelf Waters; Estuar. Coast. Shelf Sci. $50231-245$.

Farrington J W and Tripp B W 1977 Hydrocarbons in western North Atlantic surface sediments; Geochim. Cosmochim. Acta 41 1627-1641.

Fry B and Sherr E B $1984 \delta^{13} \mathrm{C}$ measurements as indicators of carbon flow in marine and freshwater ecosystems; Contrib. Mar. Sci. 27 13-47.

Garg A and Bhosle N B 2004 Abundance of macroalgal OM in biofilms: Evidence from $n$-alkane biomarkers; Biofouling 20 155-165.

Gao X, Chen S, Xie X, Long A and Ma F 2007 Non-aromatic hydrocarbons in surface sediments near the Pearl River estuary in the South China Sea; Environ. Pollut. 148 40-47.

Gogou A, Bouloubassi I and Stephanou E G 2000 Marine organic geochemistry of the Eastern Mediterranean:
1. Aliphatic and polyaromatic hydrocarbons in Cretan sea surficial sediments; Mar. Chem. 68 265-282.

Grimalt J and Albaiges J 1987 Sources and occurrence of $\mathrm{C}_{12}-\mathrm{C}_{22} n$-alkane distributions with even carbon number preference in sedimentary environments; Geochim. Cosmochim. Acta 51 1379-1384.

Harji R R, Yvenat A and Bhosle N B 2008 Sources of hydrocarbons in sediments of the Mandovi estuary and the Marmugoa harbour, west coast of India; Environ. Int. 34 959-965.

Harji R R, Bhosle N B, Garg A, Sawant S S and Venkat K 2010 Sources of OM and microbial community structure in the sediments of Visakhapatnam harbour, east coast of India; Chem. Geol. 276 309-317.

Hu L, Guo Z, Feng J, Yang Z and Fang M 2009 Distributions and sources of bulk OM and aliphatic hydrocarbons in the surface sediments of the Bohai Sea, China; Mar. Chem. 113 197-211.

Kameyama S, Tsunogai U, Nakagawa F, Sasakawa M, Komatsu D D, Ijiri A, Yamagichi J, Horiguchi T, Kawamura H, Yamaguchi A and Tsuda A 2009 Enrichment of alkanes within a phytoplankton bloom during an in situ iron enrichment experiment in western subarctic Pacific; Mar. Chem. 115 92-101.

Le Dreau Y, Jacquot F, Doumenq P, Guiliano M, Bertrand J C and Mille G 1997 Hydrocarbon balance of a site which had been highly and chronically contaminated by petroleum wastes of a refinery (from 1956 to 1992); Mar. Pollut. Bull. 34 456-468.

Mackenzie A S, Brassel S C, Eglington J and Maxwell J R 1982 Chemical fossils: The geological fate of steroids; Science 217 491-504.

Maioli O L G, Rodrigues K C, Knoppers B A and Azevedo D A 2011 Distribution and sources of aliphatic and polycyclic aromatic hydrocarbons in suspended particulate matter in water from two Brazilian estuarine systems; Cont. Shelf. Res. 31 1116-1127.

Mazurek M A and Simoneit B R T 1984 Characterization of biogenic and petroleum-derived $\mathrm{OM}$ in aerosols over remote rural and urban areas; In: Identification and analysis of organic pollutants in air (ed.) Keith L H (Boston: Ann Arbor Science/Butterworth), pp. 353-373.

Meyers P A 2003 Applications of organic geochemistry to paleolimnological reconstructions: A summary of examples, from the Laurentian Great Lakes; Org. Geochem. 34 261-289.

Mille G, Asia L, Guiliano M, Malleret L and Doumenq 2007 Hydrocarbons in coastal sediments from the Mediterranean sea (Gulf of Fos area, France); Mar. Pollut. Bull. $54566-575$.

Moldowan J M and Seifert W K 1983 Identification of an extended series of tricyclic terpanes in petroleum; Geochim. Cosmochim. Acta 47 1531-1534.

Ollivier B and Magot M 2005 Petroleum microbiology; American Society for Microbiology, Washington D.C.

Pancost R D and Boot C S 2004 The paleoclimatic utility of terrestrial biomarkers in marine sediments; Mar. Chem. 92 239-261.

Pearson A and Eglington T I 2000 The origin of $n$-alkanes in Santa Monica Basin surface sediment: A model based on compound-specific $\Delta^{14} \mathrm{C}$ and $\delta^{13} \mathrm{C}$ data; Org. Geochem. 31 1103-1116.

Peters K E and Moldowan J M 1993 The Biomarker Guide: Interpreting molecular fossils in petroleum and ancient sediments; Prentice Hall, Englewood Cliffs, New Jersey, $363 p$.

Peters K E, Walters C C and Moldowan J M 2005 The Biomarker Guide (2nd edn): Volume 1, Cambridge University Press, Cambridge. 
Raman A V 1995 Pollution effects in Visakhapatnam harbour, India: An overview of 23 years of investigations and monitoring; Helgoland Mar. Res. 49 1-4.

Readman J W, Fillmann G, Tolosa I, Bartocci J, Villeneuve J-P, Catinni C and Mee L D 2002 Petroleum and PAH contamination of the Black Sea; Mar. Pollut. Bull. 44 48-62.

Sanchez C and Permanyer A 2006 Origin and alteration of oils and oil seeps from the Sinu-San Jacinto Basin, Colombia; Org. Geochem. 37 1831-1845.

Shi H, Zhang L, Yue L and Zheng G 2008 Petroleum hydrocarbon contamination in surface sediments of Beiluohe Basins, China; Bull. Environ. Contam. Toxicol. 81 416-421.

Sonibare O O and Sojinu O S 2009 Chemical composition of leaf lipids of angiosperms: Origin of land plant-derived hydrocarbons in sediments and fossil fuel; European J. Sci. Res. 25 192-199.

Subbarao C and Subbarao N V 1994 Delineation of the effluent contaminated zones by electrical surveys at two industrial sites in Visakhapatnam, India; Environ. Geol. 24 281-286.

Sultana R and Rao D P 1998 Bioaccumulation patterns of zinc, copper, lead and cadmium in Grey mullet Mugil cephalus (L.), from harbour waters of Visakhapatnam, India; Bull. Environ. Contam. Toxicol. 60 949-955.

Tolosa I, Mesa-Albernas M and Alonso-Hernandez C M 2009 Inputs and sources of hydrocarbons in sediments from Cienfuegos bay, Cuba; Mar. Pollut. Bull. 58 1624-1634.
UNEP 1995 Determination of petroleum hydrocarbons in selected marine organisms; Reference method for Marine pollution studies No. 72; UNEP/IOC/IAEA/FAO.

Volkman J K 1986 A review of sterol markers for marine and terrigenous OM; Org. Geochem. 9 83-99.

Volkman J K 2006 Marine OM: Biomarkers, isotopes and DNA; Springer-Verlag, Heidelberg.

Volkman J K and Maxwell J R 1986 Acyclic isoprenoids as biological markers; In: Biological markers in the sedimentary record (ed.) Johns R B (Amsterdam: Elsevier), pp. $1-42$.

Volkman J K, Holdsworth D, Neill G and Bavor H 1992 Identification of natural, anthropogenic and petroleum hydrocarbons in aquatic sediments; Sci. Total Environ. $112203-219$.

Wagener A L R, Meniconi M F G, Hamacher C, Farias C O, da Silva G C, Gabardo I T and Scofield A L 2012 Hydrocarbons in sediments of a chronically contaminated bay: The challenge of source assignment; Mar. Pollut. Bull. 64 284-294.

Wang Z and Fingas M F 2003 Development of oil hydrocarbon fingerprinting and identification techniques; Mar. Pollut. Bull. 47 423-452.

Wu Y, Zhang J, Mi T and Li B 2001 Occurrence of $n$-alkanes and polycyclic aromatic hydrocarbons in core sediments of the Yellow Sea; Mar. Chem. 76 1-15.

Zaghden H, Kallel M, Louati A, Elleuch B, Oudot J and Saliot A 2005 Hydrocarbons in surface sediments from the Sfax coastal zone (Tunisia), Mediterranean Sea; Mar. Pollut. Bull. 50 1287-1294. 